\title{
KONSTRUBUSI GURU PENDIDIKAN AGAMA ISLAM DALAM MENINGKATKAN KUALITAS AKHLAK SISWA SMA NEGERI 1 PALOPO
}

\author{
1Naidinsyam \\ ${ }^{1}$ Program StudiPendidikan Agama Islam, IAIN Palopo \\ Email: naidin syam@gmail.com
}

\begin{abstract}
This research is about the contribution of Islamic education teachers in improving the moral quality of students at SMA Negeri 1 Palopo. This research is qualitative research using a philosophical and pedagogic approach. The informants consisted of the principal, the representative of the school, and the teachers. Data collection is done by observation, interview and documentation techniques. Data analysis by means of data reduction, data presentation, conclusions and data verification. For the results of the study, there are: 1) The contribution of Islamic education teachers in improving the moral quality of students at SMA Negeri 1 Palopo achieves optimal results. Based on the observations through interviews, it can e concluded that theteaching ability of Islamic education teachers is good, inviting students to do commendable activities, preventing the students from being blamed, and forming religious attitudes with the pattern of fostering religious life of students. Supported by several factors such as the involvement of school teachers, school programs, and the ability of school principals to empower the available resaources in schools. 2) There are several influential obstacles, namely: the lack of parents' education and the negative impact of advancement of science and technology. The implications of this study are expected to increase the students' moral quality into school priority, optimization of intensive coaching, principals, vice principals and teachers conduct continuous evaluations, so that the shortcomings and obstacles can be improved in the next moral development.
\end{abstract}

Keywords: Teacher's Contributions, Islamic Education, Morals.

\begin{abstract}
Abstrak
Penelitian mengenai konstribusiguru pendidikan agama Islam dalam meningkatkan kualitas akhlak siswa SMA Negeri 1 Palopo. Penelitian ini adalah penelitian kualitatif dengan menggunakan pendekatan filosofis dan pedagogik. Informan terdiri atas kepala sekolah, wakil kepala sekolah, danguru. Pengumpulan data dilakukan dengan teknik observasi, wawancara dan dokumentasi. Analisis data dengan cara reduksi data, penyajian data, kesimpulan dan verifikasi data. Hasil penelitian yaitu, 1) Konstribusi guru pendidikan agama Islam dalam meningkatkan kualitas akhlak siswa di SMA Negeri 1 Palopo telah mencapai hasil yang optimal. Di dasarkan pengamatan melalui wawancara yang menyatakan kemampuan mengajar guru pendidikan agama Islam sudah bagus, mengajak siswa melakukan kegiatan terpuji, menghindarkan siswa dari hal-hal yang tercela, serta membentuk sikap keagamaan dengan pola pembinaan kehidupan beragama siswa. Didukung oleh beberapa faktor seperti
\end{abstract}


keterlibatan guru sekolah, program-program sekolah, dan kemampuan kepala sekolah memberdayakan sumber daya yang ada di sekolah. 2) Terdapat beberapa hambatan yang berpengaruh, yaitu: minimnya tingkat pendidikan orang tua, dampak negatif dari kemajuan ilmu pengetahuan dan teknologi. Implikasi dari penelitian diharapkan peningkatan kualitas akhlak siswa menjadi perioritas sekolah, optimalisasi pembinaan yang intensif, kepala sekolah, wakil kepala sekolah dan guru melakukan evaluasi yang berkesinambungan, sehingga kekurangan dan hambatan sebelumnya dapat ditingkatkan pada pembinaan akhlak berikutnya.

Kata Kunci: Konstribusi Guru, Pendidikan Agama Islam, Akhlak.

\section{PENDAHULUAN}

Latar belakang masalah dalam tulisan ini adalah perbedaan menyangkut kapasitas intelektual, keterampilan, motivasi, persepsi, sikap, kemampuan, minat, latar belakang kehidupan dalam keluarga dan lain-lain. Perbedaan ini cenderung akan mengakibatkan adanya perbedaan pula dalam belajar setiap siswa baik dalam kecepatan belajarnya maupun keberhasilan yang dicapai siswa itu sendiri sehingga perlu adanya bimbingan dari guru. Konstribusi guru pendidikan agama Islam dalam bidang pendidikan, khususnya dalam memberi motivasi dan bagaimana meningkatkan kualitas moral siswa sangat diperlukan bimbingan guru terhadap siswa dalam bentuk apapun dalam rangka mencapai tujuan pendidikan.

Adapun rumusan masalah dalam tulisan ini yaitu : 1) Bagaimana konstribusi guru Pendidikan Agama Islam dalam meningkatkan kualitas akhlak siswa di SMA Negeri 1 Palopo. 2) Hambatan-hambatan apa yang dihadapi oleh guru Pendidikan Agama Islam dalam meningkatkan kualitas akhlak siswa di SMA Negeri 1 Palopo. 3) Upaya-upaya apakah yang ditempuh oleh guru Pendidikan Agama Islam dalam meningkatkan kualitas akhlak siswa di SMA Negeri 1 Palopo.

Tujuan penelitian ini adalah untuk 1) mendeskripsikan dan menganalisis konstrubusi Guru Pendidikan Agama Islam dalam meningkatkan kualitas akhlak siswa di SMA Negeri 1 Palopo. 2) Untuk mengetahui hambatan-hambatan apa yang dihadapi oleh Guru Pendidikan Agama Islam dalam meningkatkan kualitas akhlak siswa di SMA Negeri 1 Palopo. 3) Untuk mengungkap upaya-upaya yang ditempuh oleh Guru Pendidikan Agama Islam dalam meningkatkan kualitas akhlak siswa di SMA Negeri 1 Palopo.

Berdasarkan hasil penelitian di atas memang telah ada penelitian yang hampir sama dengan penelitian yang akan penulis lakukan, akan tetapi ada perbedaan yang mendasar, yaitu penelitian yang terdahulu hanya meneliti pembinaan dan pembentukan akhlak yang dilakukan dalam lingkup keluarga saja namun belum ada yang meneliti peran guru khususnya guru Pendidikan Agama Islam dalam proses pembinaan akhlak anak atau siswa. 
Kontribusi guru tidak kalah penting dengan konstribusi keluarga (orang tua) dalam mendidik dan membina akhlak anak. konstribusi guru sebagai pengganti orang tua di rumah, karena kesibukan atau keterbatasan pendidikan yang dimiliki orang tua maka orang tua melimpahkan tanggung jawabnya kepada sekolah yang mana seorang guru mempunyai peran yang sangat penting dalam pendidikan di sekolah. Untuk itu penulis akan mencoba mengangkat penelitian tentang konstribusi guru Pendidikan Agama Islam dalam meningkatkan kualitas akhlak siswa di SMA Negeri 1 Palopo.

Konstribusi guru yang penulis maksud dalam penelitian ini adalah peran serta atau usaha guru bidang studi pendidikan agama Islam di SMA Negeri 1 Palopo dalam mendidik, membina dan membimbing sikap atau tingkah laku siswa, ke arah yang lebih baik.

Pendidikan Agama Islam yang penulis maksudkan adalah pendidikan dengan melalui pembelajaran agama Islam di SMA Negeri 1 Palopo, yaitu berupa bimbingan dan asuhan terhadap anak didik agar nantinya setelah selesai dari pendidikan ini dapat memahami, menghayati, mengamalkan ajaran agama Islam sebagai suatu pandangan hidup demi keselamatan dan kesejahteraan hidup di dunia maupun di akherat.

Pembinaan kualitas akhlak di SMA Negeri 1 Palopo adalah proses tindakan, penanaman nilai-nilai perilaku budi pekerti, perangai, tingkah laku baik terhadap Allah swt, sesama manusia, diri sendiri dan alam sekitar yang dilakukan secara berdaya guna dan berhasil guna untuk memperoleh kebahagiaan hidup di dunia dan di akhirat.

\section{METODE}

Jenis Penelitian ini termasuk penelitian deskriptif (descriptive research), dengan mendeskripsikan sejumlah variabel yang diteliti. Metode yang digunakan dalam membahas penelitian ini adalah metode deskritif analisis.

Populasi adalah keseluruhan obyek penelitian, apakah berupa manusia, gejala-gejala, benda-benda, pola sikap, tingkah laku atau segala yang menjadi obyek penelitian. Populasi dalam penelitian ini dapat dilihat pada tabel berikut:

Tabel 1.Tabel Penyebaran Populasi Tahun 2017-2018

\begin{tabular}{lll}
\multicolumn{1}{c}{ Populasi } & \multicolumn{1}{c}{ Keterangan } & Jumlah \\
\hline Kepala Sekolah & Tahun Ajaran 2017/ 2018 & 1 \\
\hline Wakasek & Tahun Ajaran 2017/ 2018 & 4 \\
\hline \multirow{2}{*}{ Guru } & Yang aktif mengajar Tahun Ajaran 2017/ & 2 \\
& 2018 & 23 \\
\hline Siswa & Tahun Ajaran 2017/ 2018 & 30 \\
\hline Total populasi & & \\
\hline
\end{tabular}


Sumber data: Kantor SMA Negeri 1 Palopo, 5 Januari 2018

Dari data tersebut di atas diketahui bahwa jumlah populasi secara keseluruhan adalah 30 orang, dan populasi yang dijadikan sampel dalam penelitian ini 30 orang dengan menggunakan sampel acak. Hal ini dilakukan untuk mendapatkan data yang akurat dalam penelitian.

Instrumen dan teknik pengumpulan datayaitu wawancara untuk mencari data dari informan tentang sejauh mana konstribusi guru PAI dalam meningkatkan kualitas akhlak siswa di SMA Negeri 1 Palopo, upaya-upaya apakah yang ditempuh oleh Guru PAI dalam meningkatkan kualitas akhlak siswa di SMA Negeri 1 Palopo.

Peneliti menentukan fokus pertanyaan dari sumber data sebagai berikut:

a. Fokus Pertanyaan

1) Sejauh mana konstribusi guru PAI dalam meningkatkan kualitas akhlak siswa di SMA Negeri 1 Palopo

2) Upaya-upaya apakah yang ditempuh oleh Guru PAI dalam meningkatkan kualitas akhlak siswa di SMA Negeri 1 Palopo.

Adapun blanko atau form dokumentasi digunakan untuk memperoleh data dokumen konstribusi guru PAI, tentang profil sekolah, data jumlah pendidik, data jumlah kependidikan dan tenaga pendukung, dan data tentang jumlah peserta didik di SMA Negeri 1 Palopo. Data tersebut sangat membantu peneliti dalam menggabungkan data-data yang diperoleh melalui observasi dan wawancara, sekaligus dapat menggambarkan kondisi umum SMA Negeri 1 Palopo.

Dalam pengumpulan data ini, penulis menggunakan metode:

a) Interview/Wawancara, Adapun jenis wawancara yang digunakan adalah wawancara tak berstruktur. ${ }^{1}$ Pada teknik ini peneliti datang tatap muka secara langsung dengan responden atau subyek yang diteliti. Pada wawancara ini dimungkinkan peneliti dengan responden melakukan tanya jawab secara berhadapan, namun komunikasi dapat juga dilaksanakan melalui telepon. ${ }^{2}$

1 Wawancara tak berstruktur adalah wawancara yang bebas di mana peneliti menggunakan pedoman wawancara yang telah tersusun secara sistematis dan lengkap untuk pengumpulan data-datanya. Pedoman wawancara yang digunakan hanya berupa garis-garis besar permasalahan yang akan ditanyakan. Lihat Ibid., h. 233-234. 2008), h. 113.

${ }^{2}$ S. Nasution, Metode Research (Penelitian Ilmiah) (Cet. X; Jakarta: Bumi Aksara, 
b) Angket, yaitu upaya mengumpulkan data dengan cara memberikan daftar pertanyaan kepada peserta didik untuk dijawab berupa jawaban alternanif.

c) Dokumentasi,Pada teknik ini peneliti dimungkinkan memperoleh informasi dari bermacam-macam sumber tertulis atau dokumen yang ada pada responden atau tempat, di mana responden bertempat tinggal atau melakukan kegiatan sehari-harinya. ${ }^{3}$ Teknik ini digunakan untuk mencari data mengenai hal atau variabel yang dapat dijadikan sebagai informasi untuk melengkapi data-data penelitian. Data-data yang dimaksud dalam penelitian ini diambil dari profil SMA Negeri 1 Palopo.

Untuk mengetahui keabsahan data, penulis mengunakan teknik triangulasi. ${ }^{4}$ Dengan teknik triangulasi ini, penulis menggunakan beberapa sumber untuk memperoleh data, kemudian setelah memperoleh data dari sumber-sumber yang dimaksud, data diolah dan diorganisir untuk dibandingkan dengan sumber yang satu dengan sumber yang lain untuk memperoleh derajat kepercayaan data.

\section{PEMBAHASAN RUMUSAN MASALAH PERTAMA}

Keberadaan guru pendidikan agama Islam merupakan hal yang sangat penting dalam suatu organisasi, menurut Mahsyam Arif, bahwa peranan guru pendidikan agama Islam dalam membentuk sikap keagamaan siswa di sekolah adalah membimbing dan memberikan contoh, serta mengajak siswa melakukan perbuatan terpuji dan menghindari hal-hal yang tercela.

Lebih lanjut Sudirman, menjelaskan bahwa peranan guru pendidikan agama Islam sangat diharapkan untuk semaksimal mungkin dapat mengubah sikap dan karakter siswa menjadi anak yang berakhlak mulia, baik bagi dirinya sendiri maupun bagi bangsa dan negara. Suriadi Longsong menambahkan peranan guru pendidikan agama Islam dalam membentuk sikap keagamaan siswa di sekolah sangat diperlukan di mana di mana guru pendidikan agama Islam telah dibekali ilmu agama Islam yang diharapkan mampu memberikan pembinaan akhlak dan sikap siswa.

Sejalan dengan hal tersebut di atas, Nur Hikmah S mengemukakan bahwa: "Dalam proses pertumbuhan dan perkembangan siswa, sangat

${ }^{3}$ Sukardi, Metodologi Penelitian Pendidikan Kompetensi dan Prakteknya (Cet. V; Jakarta: Bumi Aksara, 2008), h. 81.

${ }^{4}$ Triangulasi adalah teknik pemeriksaan keabsahan data yang memanfaatkan sesuatu yang lain di luar data itu untuk keperluan pengecekan atau sebagai pembanding data itu. Ibid., h. 178 . 
memerlukan suatu pola pembinaan yang dapat berkesan dalam diri siswa, sekaligus dapat menjadi pendorong dalam berbuat yang terbaik, dapat membimbing ke arah pembentukan kepribadian beragama bagi siswa sangatlah urgen, karena pembinaan akhlak inilah yang dapat menjadikan siswa sebagai sosok manusia yang berkepribadian baik.

Berdasarkan beberapa penjelasan terdahulu dapat disimpulkan bahwa peranan guru pendidikan agama Islam di sekolah bukan hanya mengajarkan do'a dan tata cara ibadah kepada Tuhan saja, tapi juga berperan aktif dalam memberi motivasi kepada siswa untuk lebih baik dan lebih maju serta mampu membangun kehidupan yang lebih santun dengan landasan etika sosial yang benar. Dengan demikian seharusnya guru pendidikan agama Islam dapat menjadi pilar utama sebagai bahagian dari pendidikan secara umum untuk membangun etika sosial bangsa ini.

\section{PEMBAHASAN RUMUSAN MASALAH KEDUA}

Dalam upaya meningkatkan kualitas akhlak siswa terdapat beberapa faktor yang jadi penghambat yaitu:

1. Lingkungan masyarakat di mana siswa itu berada sangat besar pengaruhnya terhadap kesadaran beragama seseorang. Masyarakat di Jl. Pelabuhan Tangjung Ringgit sebahagian besar dari mereka yang berpendidikan rendah dan tidak mampu membina anak-anaknya sebagai mana orang-orang yang berpendidikan. Ditambah lagi pergaulan generasi mudanya yang hampir tidak mengenal batas-batas kewajaran. Sehingga berpengaruh negatif terhadap pertumbuhan jiwa beragama bagi siswa di daerah tersebut.

\section{Faktor pendidikan orang tua}

Pendidikan orang tua pada umumnya rendah sehingga mereka tidak memiliki bekal yang cukup untuk membina dan mendidik anak-anaknya apalagi dalam mengembangkan jiwa keberagaman siswa. Mugiarti salah seorang guru BK SMA Negeri 1 Palopo mengatakan bahwa ada ungkapan orang tua pesrta didik yang menyatakan bahwa untuk apa sekolah kalau pada akhimya kembali mencangkul (bertani) padahal memegang cangkul, linggis dan lain-lain tidak perlu dipelajari di sekolah. Jadi pada prinsipnya bagi mereka, yang penting anak-anak mereka dilatih bagaimana mendapatkan uang, sebab kecenderungan orang tua mereka lebih terfokus pada materi bagaimana mendapatkan materi sebanyak banyaknya.

3. Pengaruh audiovisual (televisi)

Akibat perkembangan ilmu pengetahuan masyarakat pesisir khususnya di daerah Ponjalae Palopo terkontaminasi dengan dampak negatifnya sebab 
mereka tidak mempunyai pengetahuan yang cukup untuk memilih tontonan yang positif terhadap pertumbuhan jiwa dan tayangan sinetron di TV. Sehingga setiap malam mereka menghabiskan waktunya untuk menonton sinetron. Berdasarkan informasi yang didapatkan oleh $\mathrm{Hj}$. Uswah dari salah seorang orang tua siswa menegaskan bahwa, semua ibu-ibu dan anak-anak yang masih di bawah umur pun dalam wilayah daerah Ponjalae Palopo sudah menghafal jadwal-jadwal di televisi, akibatnya baik dari segi ucapan, perilaku, bahkan cara berpakaian semuanya diikuti apa yang ditontonnya. Dan anehnya kalau ditegur jawabanya adalah sekarang zamannya gaul, nasehat-menasehati itu sudah ketinggalan zaman, sekarang itu mau-maunya gue.

Berdasarkan hasil wawancara menunjukkan bahwa kesadaran beragama dan kualitas akhlak siswa pada SMA Negeri 1 Palopo sangat minim, hal ini disebabkan beberapa faktor seperti digambarkan di atas. Untuk itu perlu dibina kerja sama antara guru (sekolah), orang tua siswa, dan pemerintah setempat. Hal ini untuk menghilangkan anggapan masyarakat bahwa pendidikan anak-רanak mereka diserahkan sepenuhnya kepada guru di sekolah, sedangkan orang tua hanya berusaha mencari nafkah. Pendapat seperti itu sangat keliru, sebab keberhasilan bagi siswa sangat tergantung sejauh mana kerja sama antara guru di sekolah sebagai perpanjangan tangan, dan orang tua dirumah menuntun, memantau dan membimbing anakanaknya untuk belajar.

Dengan demikian upaya meningkatkan kesadaran beragama dan akhlak yang terpuji terhadap peserta didik dapat tercapai dan orang tua di rumah harus terlebih dahulu memiliki kesadaran.

\section{PEMBAHASAN RUMUSAN MASALAH KETIGA}

Profesi seorang guru merupakan suatu tanggungjawab yang besar untuk mendewasakan anak didiknya. Dalam hal ini, ada beberapa upaya yang dilakukan oleh guru pendidikan agama Islam dalam meningkatkan kualitas akhlak bagi siswa di SMA Negeri 1 Palopo yang bertujuan untuk membentuk karakternya yang lebih baik. Menurut Hj. Uswah ( guru PAI ) upaya- upaya yang dilakukan antara lain :

1. Teguran langsung kepada siswa jika melihat sikap dan tingkah laku yang menyimpang dari ketentuan agama Islam.

2. Memberikan keteladan kepada anak didiknya

3. Memberikan nasehat untuk lebih memperbaiki tingkah lakunya baik dalam lingkungan sekolah maupun di luar sekolah.

Upaya lain yang dilakukan oleh guru pendidikan agama Islam dalam rangka meningkatkan kualitas akhlak bagi siswa di SMA Negeri 1 Palopo yaitu: mengadakan kegiatan amaliah ramadhan, memperingati hari-hari 
besar Islam dengan maksud agar peserta didik mengerti tentang sejarah perjuangan dan meneladani akhlak rasulullah .

Berdasarkan upaya yang telah dilakukan oleh guru pendidikan agama Islam jelaslah bahwa guru sudah berupaya semaksimal mungkin untuk memperbaiki akhlak peserta didik di SMA Negeri 1 Palopo, namun masih membutuhkan bantuan dari berbagai pihak, baik dalam lingkungan formal maupun informal.

\section{PENUTUP}

\section{Simpulan}

Berdasarkan uraian yang telah dikemukakan sebelumnya maka penulis menyimpulkan sebagai berikut: (1) konstribusi guru pendidikan agama Islam dalam meningkatkan kualitasakhlaksiswa di SMA Negeri 1 Palopo telahmencapaihasil yang optimal. Kesimpulan ini didasarkan pada pengamatan dan wawancara dengan beberapa orang yang menjelaskan bahwa kemampuan mengajar guru pendidikan agama Islam sudah bagus, mengajak siswa melakukan kegiatan terpuji, membimbing siswa agar terhindar dari hal-hal yang tercela, membina sikap keagamaan siswa dengan pola pembinaan kehidupan beragama; (2) Hambatan-hambatan yang dihadapi oleh guru pendidikan agama Islam dalam upaya peningkatan kualitas akhlak siswa di SMA Negeri 1 Palopo yaitu pengaruh lingkungan masyarakat, banyak siswa tidak mengenal batas-batas kewajaran yang sangat berpengaruh negatif terhadap pertumbuhan jiwa bagi siswa, minimnya tingkat pendidikan orang tua, dampak negatif dari kemajuan ilmu pengetahuan dan teknologi misalnya setiap malam menonton sinetron yang di dalamnya terdapat adegan-adegan porno, cara berpakaian seksi, kekerasan, percintaan.

Upaya-upaya yang dilakukan guru pendidikan agama Islam di SMA Negeri 1 Palopo dalam upaya meningkatkan kualitas akhlak bagi siswa antara lain: mengadakan amaliah Ramadan sekali setahun untuk semua kelas, memperingati hari-hari besar Islam yang dimaksudkan agar anak-anak dapat mengerti tentang sejarah perjuangan Nabi Saw. Dan upaya lain yang dilakukan oleh guru pendidikan agama Islam yaitu berupa teguran langsung kepada peserta didik jika melihat sikap dan tingkah laku yang menyimpang dari ketentuan agama Islam, memberikan keteladan kepada siswa, memberikan nasehat untuk lebih memperbaiki tingkah lakunya baik dalam lingkungan sekolah maupun di luar sekolah.

\section{Saran}

Berdasarkan kesimpulan yang telah dikemukakan diatas, maka dapat disarankan beberapa hal sebagai berikut : (1) Kepada guru agama Islam di 
sekolah ini agar lebih giat memperbanyak kegiatan keagamaan dan memahami secara cermat tentang perkembangan jiwa keagamaan pada siswa; (2) Kepada pemerintah setempat hendaknya mengambil bagian dalam pembangunan generasi mendatang dengan membantu sekolah (guru) memantau perkembangan pemahaman agama siswa di sekolah ini; dan (3) Kepada orang tua dan masyarakat agar membina hubungan yang intensif dengan sekolah dalam rangka membina siswa untuk belajar di rumah. Dengan demikian sinergitas antara sekolah, masyarakat dan pemerintah membantu siswa.

\section{DAFTAR PUSTAKA}

Sumber Buku:

Al-Abrasy, Moh. Athiyah. Dasar-dasar Pokok Pendidikan Islam. Jakarta: Rosdakarya, 1970.

Ali, Mohammad. Strategi Penelitian Pendidikan. Bandung: Angkasa, 1993.

Amin, Ahmad, Ilmu Akhlak. Bandung: Toha Putra, 1999.

Anis,Ibrahim,Al-Mu'jam Al-Wasit. Mesir: Darul Maarif, 1972.

An-Nahlawy,Abdurrahman,Pendidikan Islam di Rumah, Sekolah, dan Masyarakat. Jakarta: Gema Insani Press, 1996.

Arikunto, Suharsimi. Prosedur Penelitian Suatu Praktek. Jakarta: RinekaCipta, 1996.

Asmani, Jamal Ma'mur. Tips Menjadi Guru Inspiratif, Kreatif, dan Inovatif. Cet.I; Jogjakarta: Diva Press, 2009.

Azra, Azyumardi, Pendidikan Agama Islam. cet. III: September 2002.

Daradjat, Zakiah. Ilmu Pendidikan Islam. Jakarta: Bumi Aksara, 1996.

Membina Nilai-Nilai Moral di Indonesia. Jakarta: Bulan Bintang, 1995

Departemen Agama RI, Al-Qur'an dan Terjemahannya. Semarang: Toha Putra, 1999.

Pedoman Pengembangan Pendidikan Agama Islam. Jakarta: Dirjen Pembinaan Kelembagaan Agama Islam, 1995.

Emile, Durkheim. Moral Education, diterjemahkan oleh Lukas Ginting "Pendidikan Moral, Suatu Teoridan Aplikasi Sosiologi Pendidikan". Jakarta: Erlangga, 1990.

Jalaluddin, Psikologi Agama. Jakarta: Raja Grafindo Persada, 1998.

Kunandar, Guru Profesional Implementasi Kurikulum Tingkat Satuan Pendidikan (KTSP) dan Sukses dalam Sertifikasi Keguruan. Cet. I; Jakarta: Raja Grafindo Persada, 2007. 
Langgulung,Hasan.Manusia dan pendidikan Suatu Analisis Psikologi dan Pendidikan. Jakarta: Pusat al-Husna, 1986.

Langgulung,Hasan.Asas-asas Pendidikan Islam. Jakarta: Pustaka Al-Husna Baru, 2008.

M. Arifin. Ilmu Pendidikan Islam. Jakarta: PT. Bumi Aksara, 2003.

Majid, Abdul dan Dian Andayani, Pendidikan Agama Islam Berbasis Kompetensi. Bandung: PT. Remaja Rosdakarya Offset, 004.

Marimba, Ahmad D., Pengantar Filsafat Pendidikan Islam. Bandung: PT. AlMaarif, 1999.

Nasution, S. Metode Research. (Penelitian Ilmiah). Cet. X; Jakarta: Bumi Aksara, 2008.

Nata, Abuddin, Akhlak Tasawuf. Cet. IV; Jakarta: PT. Raja Grafindo Persada, 2002.

Poerbakawatja, Soegarda. Ensiklopedi Pendidikan. Jakarta: Gunung Agung, 1998.

Republik Indonesia. "Undang-Undang RI Nomor 32 Tahun 2004 Tentang Pemerintah Daerah," dalam Undang-Undang Republik Indonesia Tentang Otonomi Daerah 2008. Cet. I; Jakarta: Citra Wacana, 2008.

Semi, Atar, Sopan Santun Berbicara dan Menyimak. Bandung: Titian Ilmu, 1998.

Shihab, Quraih. Wawasan Al-Qur'an. Bandung; Mizan, 1996.

Sujanto,Bedjo.Manajemen Berbasis Sekolah; Model Pengelolaan Sekolah di Era Otonomi Daerah. Cet. I; Jakarta: Sagung Seto, 2007.

Sukardi. Metodologi Penelitian Pendidikan Kompetensi dan Prakteknya. Cet. V; Jakarta: Bumi Aksara, 2008.

Sukmadinata,Nana Syaodih.Pengembangan Kurikulum; Teori dan Praktek. Cet. X; Bandung: Remaja Rosdakarya, 2008.

Tatapangsara, Humaidi, Akhlak Yang Mulia. Suarabaya: PT. Bina Ilmu, 1998.

Tilaar, H.A.R. Standarisasi Pendidikan Nasional; Suatu Tinjauan Kritis. Cet. I; Jakarta: Rineka Cipta, 2006.

Undang-Undang No. 20 Tentang.Sistem Pendidikan Nasional. Cet.III; Jakarta: PT. Sinar Grafika, 2006.

Yamin,Martinis.Sertifikasi Profesi Keguruan di Indonesia.Cet.III; Jakarta : Gaung Persada Press Jakarta; 2009.

Yunus, Mahmud.Kamus Arab Indonesia. Jakarta: Yayasan Penterjemahan alQur'an, t.th.

Zahruddin dan Hasanuddin Sinaga, Pengantar Studi akhlak. Jakarta: Raja Grafindo, 2004. 